\title{
The trace fossil Lepidenteron lewesiensis (Mantell, 1822) from the Upper Cretaceous of southern Poland
}

\author{
AGATA JURKOWSKA AND ALFRED UCHMAN \\ Institute of Geological Sciences, Jagiellonian University, Oleandry 2a;30-063 Kraków, Poland. \\ E-mails:jurkowska.a@gmail.com; alfred.uchman@uj.edu.pl
}

\begin{abstract}
:
Jurkowska, A. and Uchman, A. 2013. The trace fossil Lepidenteron lewesiensis (Mantell, 1822) from the Upper Cretaceous of southern Poland. Acta Geologica Polonica, 63 (4), 611-623. Warszawa.

Lepidenteron lewesiensis (Mantell, 1822) is an unbranched trace fossil lined with small fish scales and bones, without a constructed wall. It is characteristic of the Upper Cretaceous epicontinental, mostly marly sediments in Europe. In the Miechów Segment of the Szczecin-Miechów Synclinorium in southern Poland, it occurs in the Upper Campanian-Lower Maastrichtian deeper shelf sediments, which were deposited below wave base and are characterized by total bioturbation and a trace fossil assemblage comprising Planolites, Palaeophycus, Thalassinoides, Trichichnus, Phycosiphon, Zoophycos and Helicodromites that is typical of the transition from the distal Cruziana to the Zoophycos ichnofacies. L. lewesiensis was produced by a burrowing predator or scavenger of fishes. The tracemaker candidates could be eunicid polychaetes or anguillid fishes.
\end{abstract}

Key words: Ichnofossils; Bioturbation; Terebella; Upper Cretaceous; Miechów Upland.

\section{INTRODUCTION}

Upper Cretaceous marls of epicontinental Europe contain a very distinctive trace fossil lined with fine bioclasts, including fish remains. It is called popularly "Terebella" (e.g. Bather 1911; Fuchs 1935; Arnold 1956); however, this name is inappropriate for this trace fossil, for which the ichnogenus name Lepidenteron is now in use (Suhr 1988). The origin of this trace fossil, its morphology and the nomenclatural problems, have been poorly addressed so far. Therefore, it is commonly underrepresented in descriptions, being treated as a problematic object and one better omitted (personal communication from several people); however, it represents an interesting part of palaeontological record.

Relatively well preserved specimens of Lepidenteron have been collected from upper Campanian to lower Maastrichtian marly sediments of the Miechów Segment of the Szczecin-Miechów Synclinorium in southern Poland (Text-fig. 1). Their description, interpretation, and taxonomic clarification, which are the main aims of this paper, can contribute to a better understanding of this trace fossil. 


\section{GEOLOGICAL SETTING}

In extra-Carpathian Poland, Upper Cretaceous rocks crop out in the Southern Polish Uplands, Opole Trough and the Sudety Mountains (Text-fig. 1). All of the outcrops studied are located in the southern part of the Southern Polish Uplands, within the Miechów Segment of the Szczecin-Miechów Synclinorium (Żeleźniewicz et al. 2011), called traditionally the Miechów Synclinorium (Text-fig. 1).

The Cretaceous strata of the Miechów Segment are represented by Upper Albian through Lower Maastrichtian deposits, which lie unconformably on Jurassic strata (Sujkowski 1926, 1934; Kowalski 1948; Rutkowski 1965). They are partly covered by
Miocene deposits (Text-fig. 2). Eustatically triggered transgression started in the Middle Albian and during the Turonian the sea covered the whole of the study region (Marcinowski 1974; Marcinowski and Radwański 1983, 1989), where it persisted until the midMaastrichtian (Pożaryski 1960). The Lower and Middle Campanian are composed of grey marls, opokas (siliceous limestones) with cherts, while the Upper Campanian is mainly composed of sandy opokas. During the Late Campanian, the area of the Miechów Segment was covered by a relatively shallow epicontinental sea characterized by a moderate rate of sedimentation and prevailing soft bottom conditions (Świerczewska-Gładysz and Jurkowska 2013).

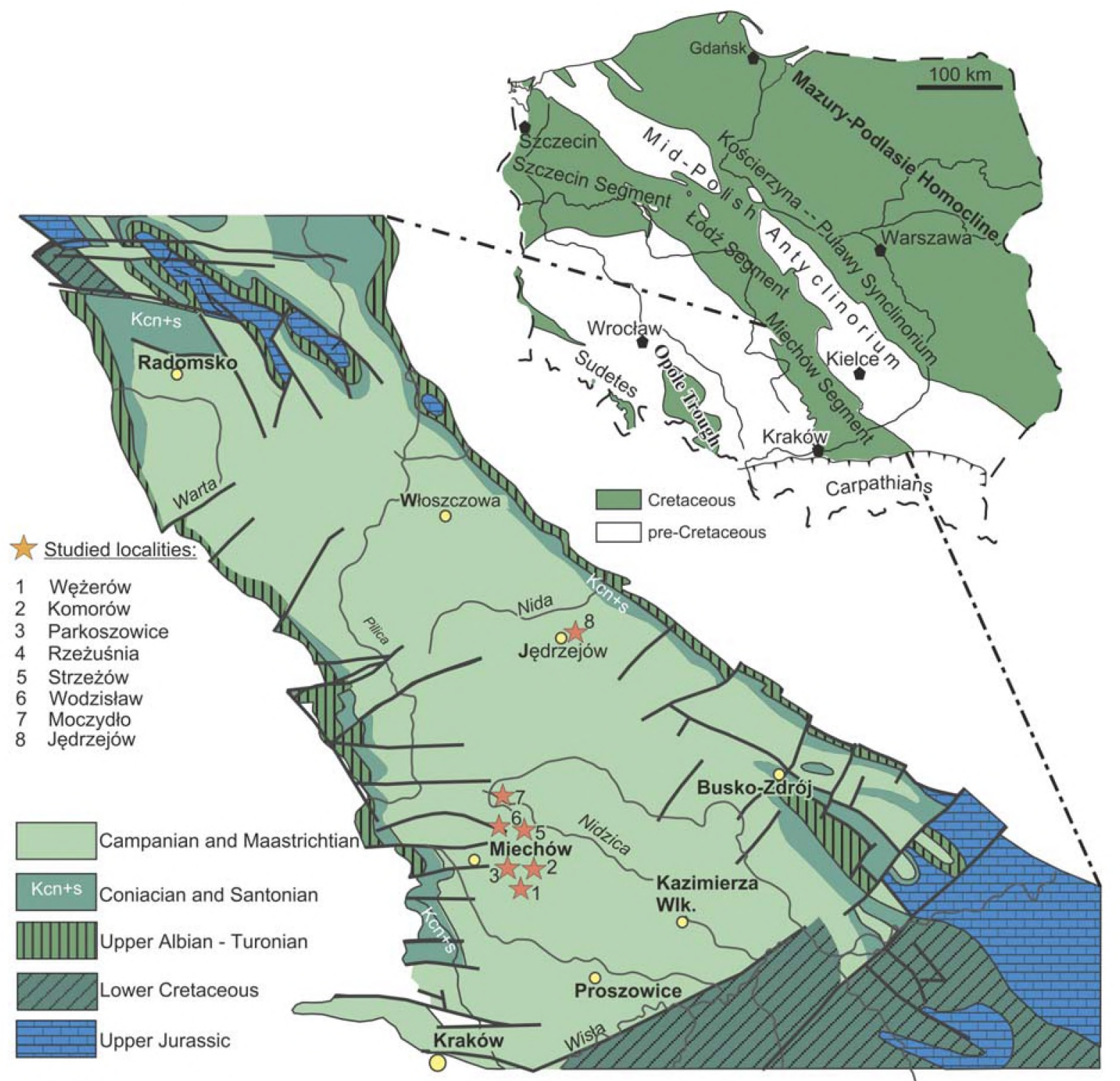

Text-fig. 1. Location map showing range of surface and subsurface Cretaceous deposits in Poland outside the Carpathians and in the Miechów Segment of the Szczecin-Miechów Synclinorium (after Dadlez et al. 2000, changed) 


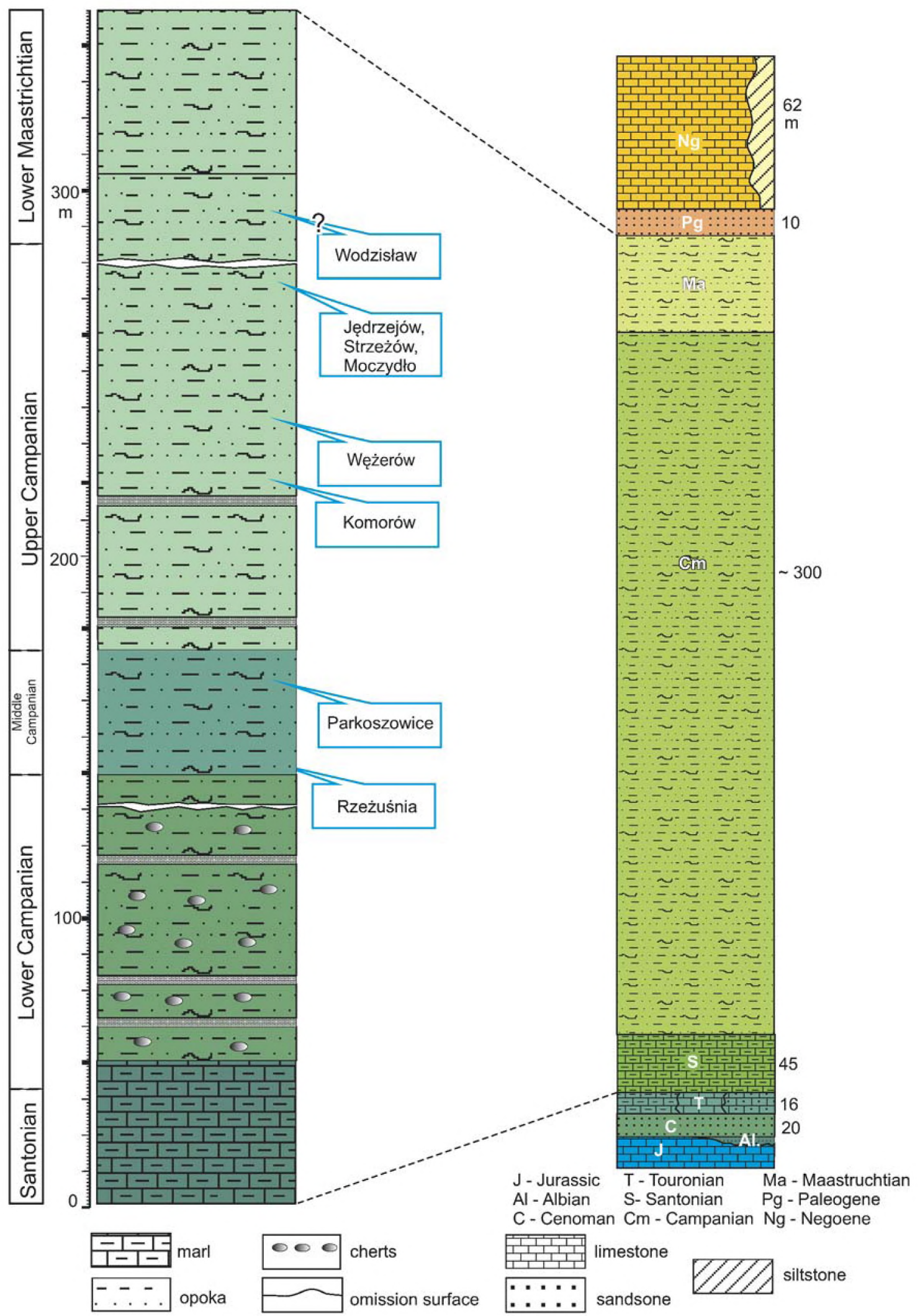

Text-fig. 2. Generalized section of the studied deposits with indication of stratigraphic position of the studied outcrops 


\begin{tabular}{|c|c|c|c|c|}
\hline Locality & GPS co-ordinates & Stratigraphy & Outcrop & $\begin{array}{l}\text { Abundance of } \\
\text { Lepidopteron }\end{array}$ \\
\hline Jędrzejów & $\begin{array}{l}\text { N50 } 31^{\prime} 5.05^{\prime \prime} \\
\text { E020 } 17^{\prime} 4.76^{\prime \prime}\end{array}$ & Upper Campanian & $\begin{array}{l}\text { Temporary road cutting, } \\
\text { northern part of the town of } \\
\text { Jędrzejów, } 4 \mathrm{~m} \text { thick sandy } \\
\text { opokas }\end{array}$ & $\begin{array}{l}\text { Abundant in } \\
\text { the lower part }\end{array}$ \\
\hline Komorów & $\begin{array}{l}\text { N50 } 11^{\circ} 45.38^{\prime \prime} \\
\text { E020 } \\
1^{\prime} 1.1^{\prime \prime}\end{array}$ & Upper Campanian & $\begin{array}{l}\text { Natural outcrop, } 3 \mathrm{~m} \text { thick, } \\
\text { opokas with marly } \\
\text { intercalations }\end{array}$ & Rare \\
\hline Moczydło & $\begin{array}{l}\mathrm{N} 50^{\circ} 28^{\prime} 48.91 " ; \\
\mathrm{E} 020^{\circ} 12^{\prime} 9.45^{\prime \prime}\end{array}$ & Upper Campanian & $\begin{array}{l}\text { Inactive quarry, } 3 \mathrm{~m} \text { thick, } \\
\text { opokas with fossils }\end{array}$ & Common \\
\hline Parkoszowice & $\begin{array}{l}\text { N50 } 18^{\prime} 59.39^{\prime \prime} \\
\text { E020 }\end{array}$ & ?Middle Campanian & $\begin{array}{l}\text { Inactive quarry, } 6 \mathrm{~m} \text { thick, } \\
\text { opokas (glauconite in upper } \\
\text { part), with abundant fossils }\end{array}$ & $\begin{array}{l}\text { Abundant in } \\
\text { the lower part }\end{array}$ \\
\hline Rzeżuśnia & $\begin{array}{l}\text { N50²0'9.98"; } \\
\text { E019 } 58^{\prime} 15.53^{\prime \prime}\end{array}$ & Middle Campanian & $\begin{array}{l}\text { Inactive quarry, } 18 \mathrm{~m} \text { thick, } \\
\text { opokas and opokas with } \\
\text { cherts (Jagt et al., 2004; } \\
\text { Świerczewska-Gładysz and } \\
\text { Jurkowska, 2013) }\end{array}$ & Common \\
\hline Strzeżów & $\begin{array}{l}\text { N50 } 22^{\prime} 28.3^{\prime \prime} \\
\text { E020 } 24^{\prime} 7.38^{\prime \prime}\end{array}$ & Upper Campanian & $\begin{array}{l}\text { Inactive quarry, } 7 \text { m thick, } \\
\text { sandy opokas, very } \\
\text { abundant fossils } \\
\text { (Świerczewska-Gładysz } \\
\text { and Jurkowska, 2013) }\end{array}$ & Common \\
\hline Wężerów & $\begin{array}{l}\text { N50 } 16^{\prime} 14.51^{\prime \prime} \\
\text { E020 }\end{array}$ & Upper Campanian & $\begin{array}{l}\text { Natural outcrop, } 3 \mathrm{~m} \text { thick, } \\
\text { opokas with marly } \\
\text { intercalations, }\end{array}$ & Rare \\
\hline Wodzisław & $\begin{array}{l}\text { N50 } 27^{\prime} 32.68^{\prime \prime} \\
\text { E020 }\end{array}$ & $\begin{array}{l}\text { Lower } \\
\text { Maastrichtian }\end{array}$ & $\begin{array}{l}\text { Artificial outcrop, } 4 \mathrm{~m} \\
\text { thick, sandy opokas, rare } \\
\text { fossils }\end{array}$ & Rare \\
\hline
\end{tabular}

Table 1. List of studied localities, their GPS co-ordinates, stratigraphic position and character of outcrop

The trace fossil Lepidenteron was recognized in seven outcrops, six of which are located in the Miechów area (SW part of the Miechów Segment) and one (Jędrzejów) in the NE part of the Miechów Segment (Textfig. 1, Table 1). The Jędrzejów section is no longer accessible because it was exposed in a temporary road cutting in the northern part of the town of Jędrzejów (Świerczewska-Gładysz and Jurkowska 2013).

\section{THE TRACE FOSSIL LEPIDENTERON}

\section{Lepidenteron Frič, 1878}

TYPE ICHNOSPECIES: Lepidenteron lewesiensis (Mantell, 1822), originally Lepidenteron longissimum Frič, 1878, which was maintained by Howell (1962) but included in L. lewesiensis (Mantell, 1822) by Suhr (1988).

EMENDED DIAGNOSIS: Unbranched tubular structure without a wall, partly lined with bioclasts. Orien- tation to the bedding variable; terminations mostly diffuse, not associated with any discontinuity surface.

DISCUSSION: Suhr (1988) provided a diagnosis of Lepidenteron. However, due to its interpretative elements (reference to the ethological category domichnia and to sedentary worms as tracemakers), this diagnosis does not meet the recommended and widely accepted diagnostic criteria, i.e. ichnotaxobases (Bertling et al. 2006). Moreover, the diagnosis refers to bioclasts glued to the wall (Röhrenwand), but the trace fossil does not have an actively produced structure that can be called a wall sensu Bromley (1996). Furthermore, other trace fossils contain bioclasts incorporated into a real wall and they should be separated from Lepidenteron.

Suhr (1988) also included values of diameter and length of Lepidenteron in the diagnosis, $0.5-40 \mathrm{~mm}$, and up to more than $30 \mathrm{~cm}$, respectively. Size is generally not accepted as an ichnotaxobase (Bertling et al. 2006), although some caution is necessary, because some large tetrapod burrows with bones at the bottom 
can meet the diagnosis. The selection of ichnotaxobases should be inspired by biological interpretation (Fürsich 1974; Bertling et al. 2006). Therefore, possible inclusion of large tetrapod burrows in Lepidenteron would on the basis of such a broad diagnosis contradict the recommendation that ichnotaxobases should be as close as possible to the biological reality. Therefore, in the emended diagnosis, the prevailing diffuse terminations in Lepidenteron without any association with a discontinuity surface are proposed as the diagnostic criteria, these being scarcely applicable to tetrapod burrows.

Trace fossils can contain bioclasts in their passive fill (commonly in crustacean burrows, e.g. Thalassinoides) which do not relate to the behaviour of the
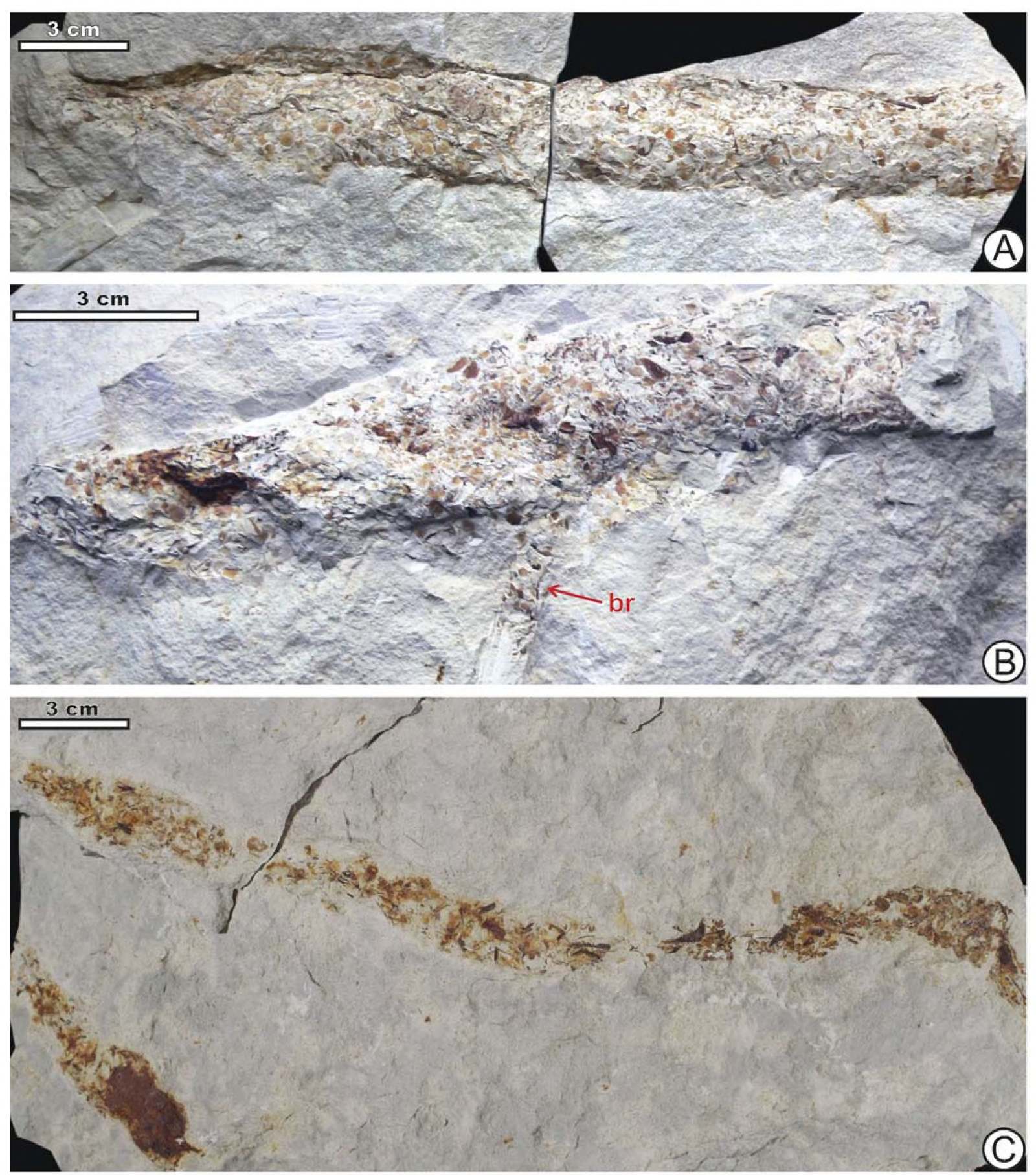

Text-fig. 3. General view of Lepidenteron lewesiensis (Mantell, 1822) on a parting surface of opoka marls. A - Longest specimen with the tapering termination on the left side, Parkoszowice, INGUJ220P/L/2. B - Specimen with a side, possible false branch (br), Moczydło, INGUJ220P/L/1. C - Slab with two specimens; the longer one displays winding course, Parkoszowice, INGUJ220P/L/17 
tracemaker. This is not the case with Lepidenteron, because the bioclasts in the type ichnospecies are ordered, always taxonomically selected, i.e. limited to fish remains, and it does not appear to be associated with any sedimentary discontinuity, from which the burrow could pipe down. Some trace fossils contain bioclasts as an important part of their morphology and the bioclasts relate to the behaviour of the tracemaker. They include Diopatrichnus Kern, 1978, Crininicaminus Ettensohn, 1981, Nummipera Hölder, 1989, Baronichnus Breton, 2002, and Ereipichnus Monaco et al., 2005, which, however, differ from Lepidenteron Frič, 1878 in many aspects.

Diopatrichnus Kern, 1978 shows bioclasts attached outside a distinct constructed wall (Gibert 1996). Nummipera Hölder, 1989 displays a thick wall composed
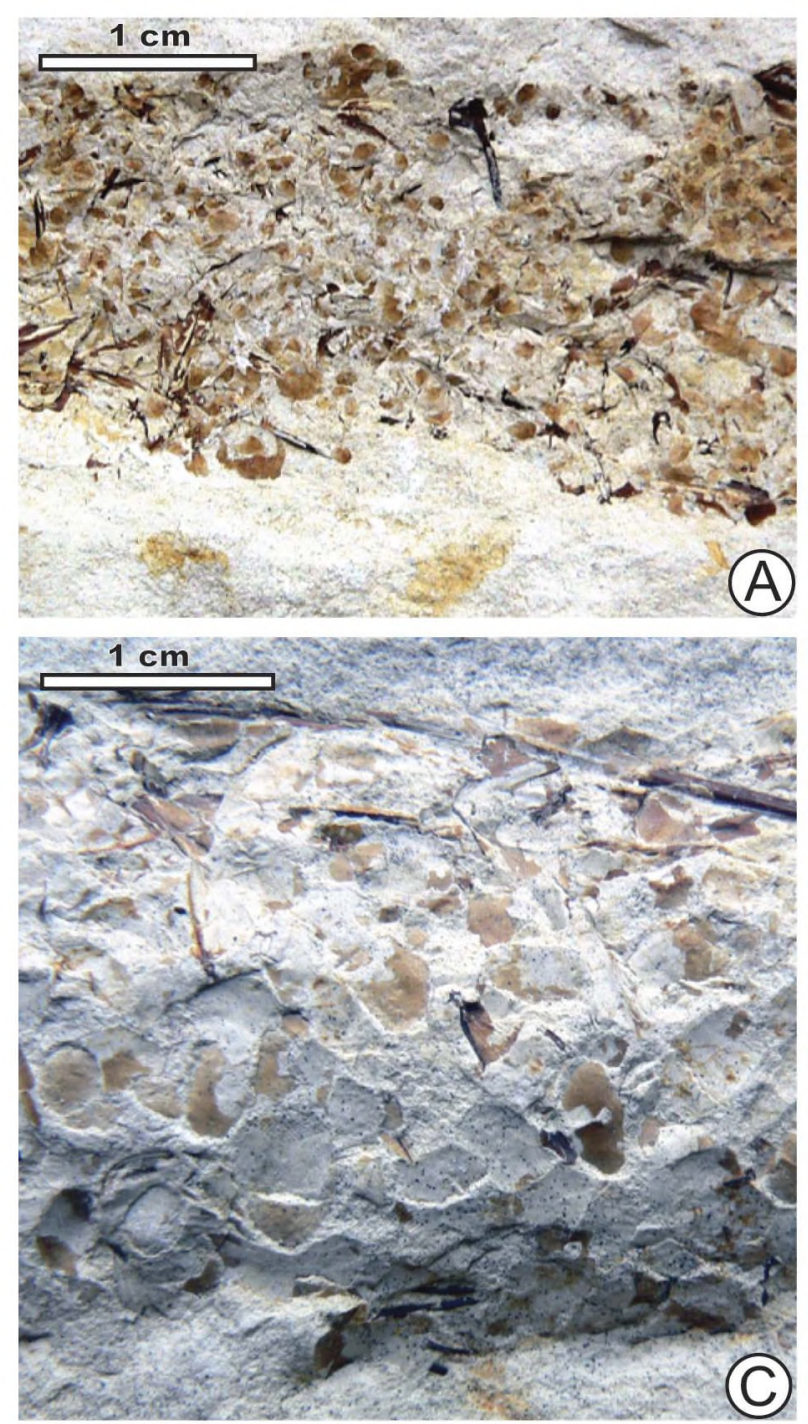

mostly of large foraminiferids (Jach et al. 2012). Baronichnus Breton, 2002 also displays a distinct wall built of bryozoan zoaria (Breton, 2002). Ereipichnus Monaco et al., 2005 is characterized by a very thick wall composed of imbricated bioclasts, mainly orbitolinid foraminiferids (Monaco et al. 2005). Crininicaminus Ettensohn, 1981 (described as a biotaxon, but in fact an ichnotaxon; Jach et al. 2012) is a slightly tapered tube, with a wall composed of densely packed crinoidal ossicles. All these ichnogenera display a constructed wall, a feature in which they differ substantially from Lepidenteron, which has no such wall.

\section{Lepidenteron lewesiensis (Mantell, 1822)}

(Text-figs 3-5)
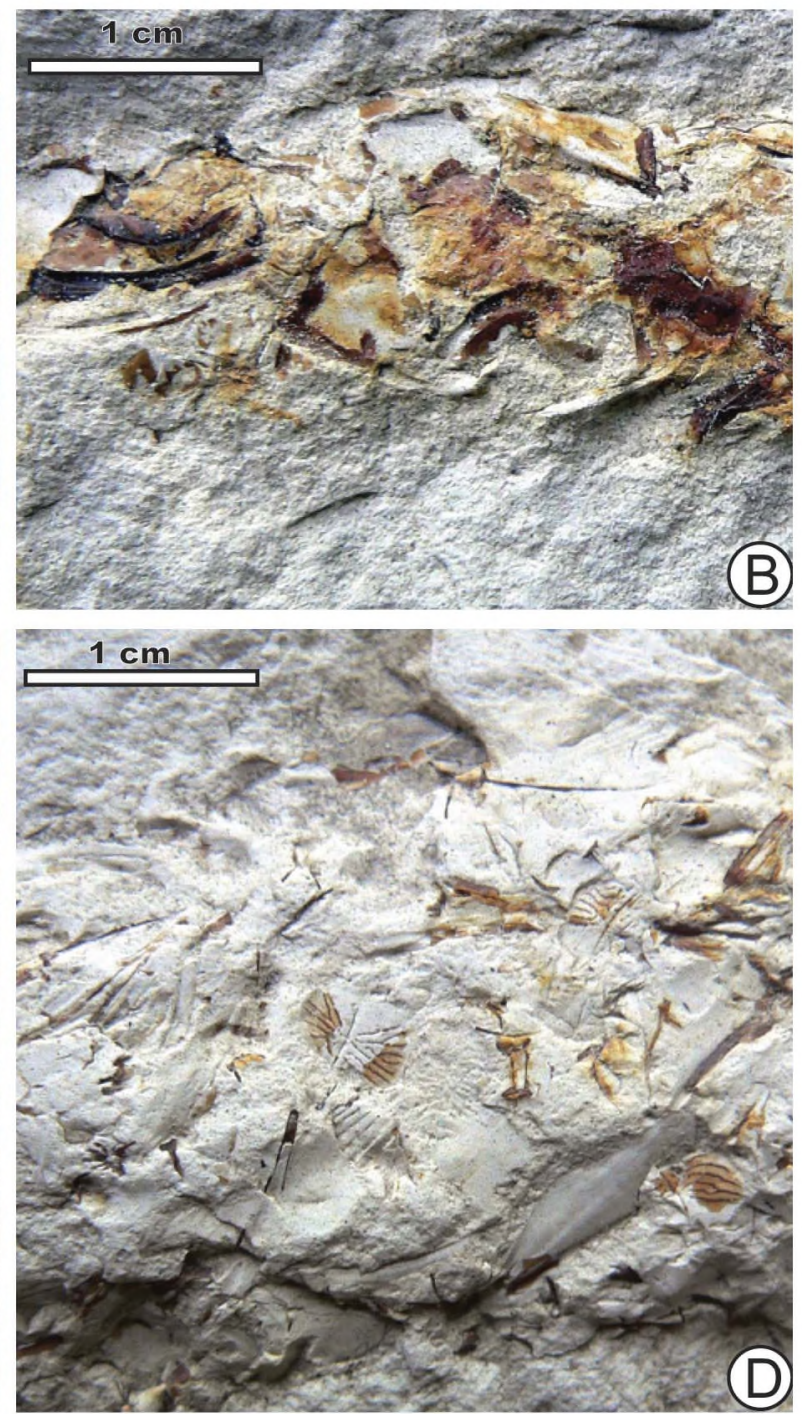

Text-fig. 4. Details of Lepidenteron lewesiensis (Mantell, 1822) on parting surfaces of opoka marls. A - fill with small fish scales and bones, Strzėzów, INGUJ220P/L/24. B - fill with larger fish bones and scales, Parkoszowice, INGUJ220P/L/17. C - fill with larger fish scales and rare fish bones, Parkoszowice, INGUJ220P/L/2. D - fill with ornamented fish scales and rare fish bones, Wodzisław, INGUJ220P/L/4 


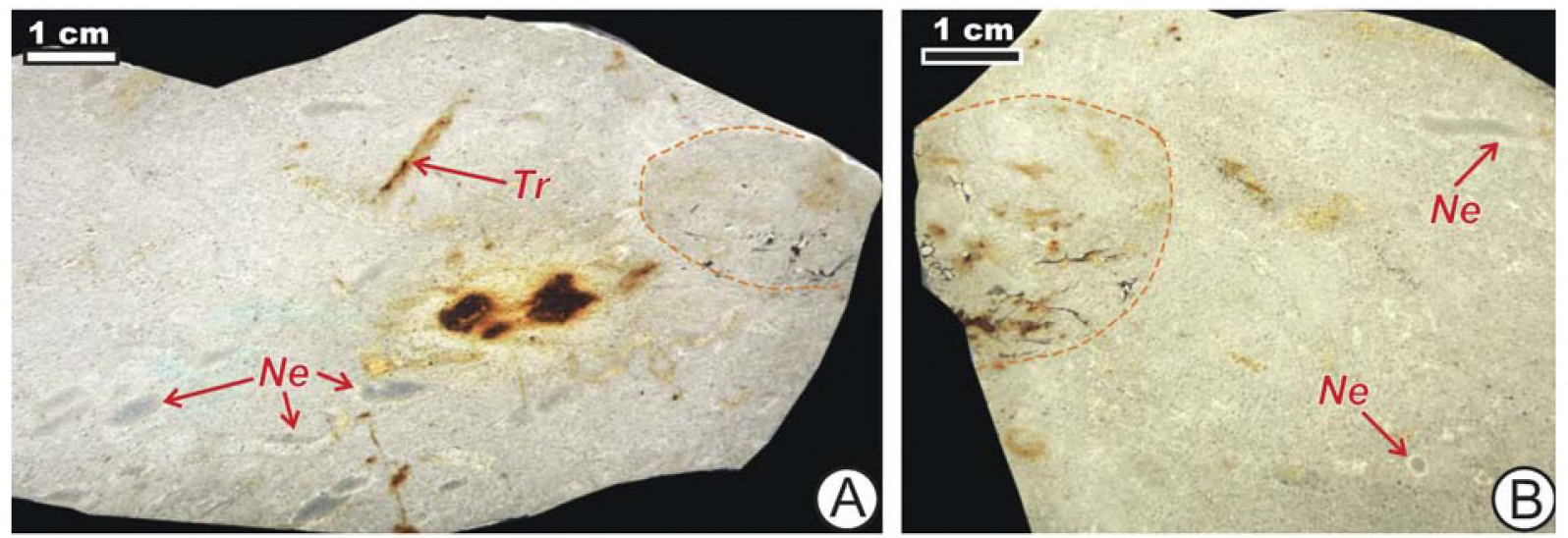

Text-fig. 5. Lepidenteron lewesiensis (Mantell, 1822) in cross section encircled with dashed line; polished surfaces. A - totally bioturbated background, Nereites isp. (Ne), Trichichmus isp. (Tr) and unknown ferruginized object in the middle, Strzeżów, INGUJ220P/L/5. B - totally bioturbated background, Nereites isp. (Ne); the cross section is somewhat oblique, Strzeżów, INGUJ220P/L/5

SYNONYMY: As in Suhr (1988).

EMENDED DIAGNOSIS: Lepidenteron in which bioclasts are composed of fish scales and bones in varying proportions. A tapering of the burrow before the termination may be present.

REMARKS ON THE DIAGNOSIS: The diagnosis of Lepidenteron lewesiensis provided by Suhr (1988) contains the same problems as the diagnosis of the ichnogenus. Therefore, it is emended herein.

MATERIAL: 23 slabs with single specimens. They are housed in the Institute of Geological Sciences of the Jagiellonian University (institutional abbreviation INGUJ220P). The slabs are white marly opokas, microscopically packstones with planktonic and benthic foraminiferids and spicules of siliceous sponges. Other bioclasts include fragments of bivalves and rare echinoid tests. The content of quartz grains can be significant.

DESCRIPTION: Tubular, mostly straight, rarely gently curved or gently winding structure, which is $9-35 \mathrm{~mm}$ wide (mean value $18.36 \mathrm{~mm} ; \mathrm{n}=23$ ). In most specimens, the width is uniform along the burrow. Rarely, a gentle, irregular swelling can be present (Text-fig. 3B). The burrow is elliptical in cross section, but without any wall (Text-fig. 5). The short axis of the ellipse is up to $9 \mathrm{~mm}$ long. The outline of the burrow is seen only due to the poor colour contrast between the burrow fill and the surrounding rock. The longest observed burrow is at least $275 \mathrm{~mm}$ long; however, the termination of the burrow is not very clear. Mantell (1822) reported $L$. lewesiensis more than $60 \mathrm{~cm}$ long. Most of the specimens are incomplete and the burrow is truncated by the slab edge. In some specimens, the termination is diffuse, shown by the gradual disappearance of the bioclasts. Rarely, a tapering of the burrow before the termination is observed (Text-fig. 3A), similar to that illustrated by Suhr (1988, pl. 1, fig. 1). Most burrows are horizontal, less frequently oblique. Their margin is uneven, without any evidence of a wall.

The most characteristic feature of the trace fossil is its fill. Close to the lower margin of the burrow, brownish, shining bioclasts are concentrated (Text-fig. 5). Most of them are oval fish scales, rarely elongated fish remains, mainly fragments of bones (Text-fig. 4). Most of the scales are semi-transparent, up to $3 \mathrm{~mm}$, rarely up to $7 \mathrm{~mm}$ wide. The mean size of the scales can differ between specimens. Some of them display the original ornamentation (Text-fig. 4D). The elongated elements are up to $13 \mathrm{~mm}$ long. They are fragments of small bones and fin rays and can constitute up to a few percent of the bioclasts. Most of the bioclasts are oriented approximately parallel to the burrow margin, but within a wide angle of inclination. The inclination of adjacent scales may vary significantly. Most of the elongated elements are parallel or oblique to the burrow axis, but without distinct alignment. The remaining part of the burrow is filled with marly sediment, which is the same as the host rock.

\section{DISCUSSION}

\section{Nomenclatural aspects}

Lepidenteron has been interpreted variously and described under different names. It was considered a fossil fish (Muraena? lewesiensis Mantell, 1822 or Dercetis elongatus Münster and Agassiz in Agassiz, 
1843 and in Mantell 1844, 1851), a coprolite (Frič 1869; Roll 1931) or a plant (Suhr 1988 for review). Frič (1877) and Davies (1879) discussed a possible interpretation as a burrow of the polychaete Terebella and therefore Davies (1879) called it Terebella lewesiensis (Mantel1, 1822). However, neither Muraena Linnaeus and Dercetis Münster and Agassiz in Agassiz as genera of fishes, nor Terebella Linnaeus as a genus of a polychaete, can be applied to trace fossils. Frič (1878) established Lepidenteron longissimum for the trace fossil under discussion, and therefore Lepidenteron has priority.

Lepidenteron lewesiensis is distinguished by the presence of fish biodetritus from other ichnospecies of Lepidenteron. Lepidenteron mantelli (Geinitz, 1850) is characterized by an internal lining of plant detritus, $L$. cancellata (Bather, 1911) by a lining of particles of sediment, and L. variabilis Suhr. 1988 by a lining composed of lithoclasts and bioclasts (see Suhr 1988 for review).

\section{Ethological and palaeoenvironmental interpretation}

To date, Lepidenteron lewesiensis is interpreted as a domichnial burrow of a terebelloid polychaete living in deeper water (up to $200 \mathrm{~m}$ ), with an age range from the Middle Jurassic to the Cainozoic (Miocene) (Suhr 1988). This interpretation can be partly challenged. One can interpret it as a coprolite (Frič 1869; Häntzschel 1931; Roll 1931), but Lepidenteron lewesiensis is not always horizontal. An oblique orientation suggests that the fish remains are within a burrow. The burrow, however poorly outlined, is still visible (Text-fig. 5). The fill of a burrow, even if coprolitic in origin, is still an element of the burrow. The burrow is a sort of domichnion, but without the wall that is a typical element of the burrows of the terebelloid polychaetes Diopatra, Lanice and Owenia (see Gibert 1996; Jach et al. 2012 for discussion), and which can be expected in burrows in soft sediment. The fish detritus does not form part of a constructional wall, which could serve as a reinforcement of the burrow against collapse. Neither fish scales nor fish bones are observed in the surrounding rocks. It seems to be unlikely that the tracemaker collected the detritus particle by particle from the sediment surface. The detritus is concentrated in the lower part of a burrow and seems to represent waste after consumption. The presence of bioclasts on the lower side of the burrow confirms this hypothesis. However, Davies (1879) mentioned two specimens with bioclastic lining on both sides of the burrow. It is therefore suggested that the tracemaker was either a carnivorous fish, living hidden in sediment and hunting on the sea floor, or a fish scavenger, feeding on fish carcasses. Davies (1879) related the fish detritus to a few fish taxa, but it is not clear whether this was in one specimen or in several specimens. The general lack of fish vertebrae or head bones is puzzling, but these could have been left on the surface, while scales and small bones could have been defecated in the burrow. Davies (1879) noted rare occurrences of very small vertebrae in the Lepidenteron lining. The tracemaker could have been interested in hiding its own faeces as a protection against predators. It is also possible that the tracemaker consumed only pieces of fish, without vertebrae or head, within the sediment. In this case, only small fish remnants would have been preserved in deeper levels of the sediment. It is also not excluded that the fish was entirely consumed in the burrow and that the larger waste particles were then removed to avoid them blocking the burrow. On the other hand, the fish could have been too large to be consumed within the burrow.

Possible candidates for the tracemaker should be searched for among animals that are 9-35 $\mathrm{mm}$ in diameter, rather long, able to burrow, and live in a tube connected to the sea floor.

One possible candidate is a predatory eunicid worm (family Eunicidae) similar to the recent omnivorous bobbit worm Eunice aphroditois (Pallas) (see Knox and Green 1972; Fauchald and Jumars 1979), which sits buried in the sediment and actively hunts fishes swimming above. This species lives in warmer seas worldwide on sandy, gravelly and muddy bottoms, at a depth of 5 to $20 \mathrm{~m}$, and can be up to $3 \mathrm{~m}$ long and up to $25 \mathrm{~mm}$ in diameter (Gayle 2012; Fauchald and Bellan 2013).

Carnivorous or scavenging fishes, which are able to burrow, are also possible tracemakers of Lepidenteron. For instance, eels (Anguilliformes) are able to burrow in sediment and commonly hunt fish and scavenge fish carcasses (e.g. Tesch 2003). The Recent anguillid Pisodonophis cancrivorus (Richardson) can burrow quickly in sand and, with only its head projecting, hunt for other fishes (McCosker and Castle 1986). Davies (1879) noted that Lepidenteron lewesiensis (his Terebella lewesiensis) was known to the quarrymen as the "petrified eel". Indeed, it can be compared to a hunting eel, buried in sediment, with the upper part of the body inclined and the lower part horizontal.

Other candidates that can be considered come from stomatopod crustaceans, which live mostly in shallow and warm seas, some of which are burrowing and carnivorous animals (Ferrero 1989; Brwon and Chivers 2005; Reaka et al. 2009). Most crustacean burrows are branched, but the stomatopod Hemisquilla californien- 
sis Stephenson produces simple shafts that can be almost $2 \mathrm{~m}$ long and $8-10 \mathrm{~cm}$ in diameter (Caldwell 2007). These burrow dimensions are somewhat too large compared to those of Lepidenteron, but smaller burrows are also possible. Nevertheless, all stomatopod burrows are open, rarely branched (Bromley 1996) and their margins or wall should be seen in the fossil record.
Jurassic burrows ascribed to Thalassinoides and referred to stomatopods were presented by Monaco and Garassino (2001) and Monaco and Giannetti (2002). Lepidenteron lewesiensis is unbranched, has no distinct terminations and displays terminal constrictions. All of these features exclude stomatopods as possible tracemakers.
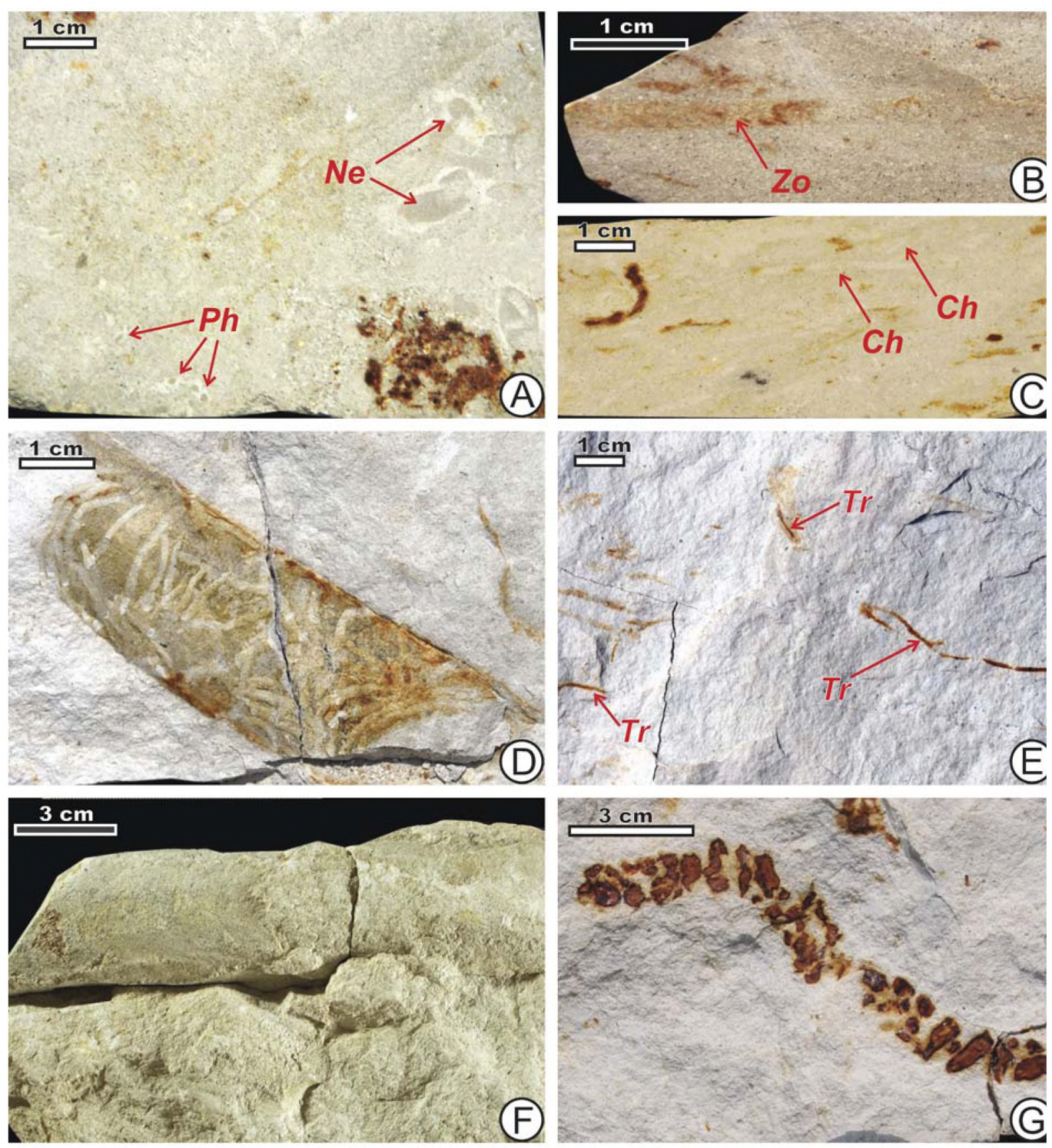

Text-fig. 6. Associated trace fossils. A-totally bioturbated background sediment, Nereites isp. (Ne), Phycosiphon isp. (Ph); polished slab, Strzeżów, INGUJ220P/L/22. B - planar structure visible on both sides of the specimen determined as Zoophycos isp. (Zo); vertical polished surface, Wężerów, INGUJ220P/L/25. C - totally bioturbated background sediment, cross-sections of Chondrites isp. (Ch); polished surface, Strzeżów, INGUJ220P/L/21. D - internal mould of the cephalopod Baculites sp. covered with Chondrites isp., parting surface, Rzeżuśnia, field photograph. E - Trichichnus isp. (Tr) on rough surface, Rzeżuśnia, field photograph. F - large tubular burrow (?Thalassinoides isp.), parting surface, Parkoszowice, INGUJ220P/L/23. G - Helicodromites isp., parting surface, Parkoszowice, INGUJ220P/L/24 
One of the problems with the tracemaker candidates is the fact that they are known mostly from shallow seas, whereas the Lepidenteron material under discussion occurs in marine sediments deposited below storm wave base. This is evidenced by total bioturbation of sediments, with no bed of tempestite, and by the occurrence of a trace fossil assemblage that points to a transition from the distal Cruziana ichnofacies to the Zoophycos ichnofacies (e.g. Pemberton et al. 2001; Buatois and Mángano 2011). The assemblage includes Planolites, Thalassinoides, Trichichnus, Nereites, Phycosiphon, Zoophycos and Helicodromites (Text-fig. 6). The latter four ichnotaxa, in particular, are characteristic of a deeper sea. Nevertheless, the study area was covered by an epicontinental sea (ŚwierczewskaGładysz and Jurkowska 2013), not deeper than a shelf sea. It is not excluded that the deeper shelf zone of the Late Cretaceous seas could have been inhabited by representatives of eunicid polychaetes oranguillid fishes, which are the candidates for the producer of Lepidenteron.

The stratigraphic ranges of the tracemaker candidates also present problems. The oldest eunicids derive from the Ordovician (Kielan-Jaworowska 1966), and the oldest stomatopods are dated to the Carboniferous (Hof 1998). The first anguillid fish is known from the Cenomanian (Belouza et al. 2003; Santini et al. 2013), but Suhr (1988) concluded that Lepidenteron lewesiensis ranged at least from the Middle Jurassic. The range of the ichnogenus can be extended even further, because Zapfe (1949) described a burrow, $30 \mathrm{~mm}$ in diameter, lined with fragments of shells and fish scales from the Rhaetian of Austria. The presence of shell debris, however, is not observed in Lepidenteron lewesiensis. The later occurrence of anguillid fishes than L. lewesiensis call in question the anguillid candidature, but this is not the first time when the trace fossil record precedes the body fossil record. It is actually possible that the tracemaker of L. lewesiensis is still living today, but our current knowledge of deeper water burrowing organisms is incomplete.

So far, the trace fossil Lepidenteron lewesiensis is limited to Europe. Most specimens derive from Upper Cretaceous epicontinental sediments, mainly from the chalk and related facies, including sandstones. The absence of Lepidenteron in North America is intriguing. The Atlantic Ocean could be considered as a barrier; however, there was no deep sea between North America and Europe until the Turonian (Ziegler 1988). It is possible that this trace fossil may exist in North America but has been ignored so far. Mantell (1822, 1844, 1851) described Lepidenteron from the Cenomanian-Maastrichtian Chalk of England (see also Agassiz 1843; Davies 1879; Bather 1911). Other finds come from rocks of the same age in the Czech Republic (Frič, 1869, 1878, 1883, 1889, 1893), Germany (Voigt 1928; Abel 1935; Kukuk 1938; Haller 1963; Arnold 1956, 1964), the Maastrichtian of The Netherlands (Friedman 2012), the lower Maastrichtian of Denmark (Ravn 1915; Rosenkrantz 1920, 1967) and the Campanian of Sweden (Köpinge Sandstone; Grönwall 1912). A larger form (over $40 \mathrm{~mm}$ in diameter) from the Gault facies in England (Albian) described as "Terebella" lutensis by Bather (1911) was included in Lepidenteron lewesiensis by Suhr (1988).

\section{CONCLUSIONS}

Lepidenteron Frič, 1878 is an unbranched and unwalled trace fossil that is lined with bioclasts; the absence of a constructed wall composed of bioclasts distinguishes it from Diopatrichnus Kern, 1978; Crininicaminus Ettensohn, 1981, Nummipera Hölder, 1989; Baronichnus Breton, 2002 and Ereipichnus Monaco et al., 2005. A Recent unnamed burrow actively filled with foraminiferids was presented by Kaminski and Wetzel (2004). Lepidenteron lewesiensis (Mantell, 1822) is lined with small fish scales and bones. It is common in Upper Cretaceous epicontinental, mostly marly sediments in Europe. In the study area, it occurs in middle Campanian-lower Maastrichtian deeper shelf sediments deposited below wave base. They contain a trace fossil assemblage that displays transitional features from the distal Cruziana to the Zoophycos ichnofacies. $L$. lewesiensis was produced by a burrowing predator or scavenger of fishes and the fish debris within the burrow probably represents indigestible waste from feeding. The tracemaker could belong to eunicid polychaetes or anguillid fishes, which, apart from their prevailing shallow-marine habitat, could also be expected to live in sediments deposited in greater water depths.

\section{Acknowledgements}

Support was given by the National Science Center (grant number: PRO-2011/01/N/ST10/07717) and by the Jagiellonian University (DS funds). The paper benefited from reviews by Andreas Wetzel (Basel) and Paolo Monaco (Perugia).We thank Ireneusz Walaszczyk (Warsaw) and Christopher J. Wood ( U.K) for constructive rewiews and linguistic corrections. 


\section{REFERENCES}

Abel, O. 1935. Vorzeitlichte Lebensspuren, pp. 1-644. Gustav Fischer; Jena.

Agassiz, L. 1833-1843. Recherches sur les poissons fossiles, tome 2, pp. 1-337. Imprimerie de Petitpierre; Neuchâtel.

Arnold, H. 1956. Terebella lutensis Bather in der Münsterländer Oberkreide. Paläontologische Zeitschrift, 30, 58.

Arnold, H. 1964. Fossilliste für die Münsterländer Oberkreide. Fortschritte in der Geologie von Rheinland und Westfalen, 7, 309-330.

Brown, G.E. and Chivers, D.P. 2005. Learning as an adaptive response to predation. P. Barbosa and I. Castellanos (Eds), Ecology of Predator-Prey Interactions, pp. 34-54. Oxford University Press.

Bather, F.A. 1911. Upper Cretaceous terebelloids from England. Geological Magazine, 8, 481-487 and 549-556.

Belouza, A., Gayet, M. and Atallach, C. 2003. Les premiers Anguilliformes: I. Révision des genres cénomaniens $A n-$ guillavus Hay, 1903 et Luenchelys nov. gen. Geobios, 36, 241-273.

Bertling, M., Braddy, S., Bromley, R.G., Demathieu, G.D., Genise, J.F., Mikuláš, R., Nielsen, J.K., Nielsen, K.S.S., Rindsberg, A.K., Schlirf, M. and Uchman, A. 2006: Names for trace fossils: a uniform approach. Lethaia, $\mathbf{3 9}$, 265-286.

Breton, G. 2002. Baronichnus armatus igen. nov., isp. nov. un fouisseur du tuffeau turonien de Touraine arme son terrier de bryozoaires. Bulletin trimestriel de la Société Géologique de Normandie et des Amis du Muséum du Havre, 87, $29-37$.

Bromley, R.G. 1996. Trace Fossils: Biology, Taphonomy and Applications, 2nd edition, pp. 1-361. Chapman \& Hall; London

Buatois, L.A. and Mángano, M.G. 2011. Ichnology: Organisms-Substrate Interactions in Space and Time, pp. 1-358. Cambridge University Press; Cambridge.

Caldwell, R.L. 2007. Stomatopoda. In: J.T. Carlton (Ed.), Intertidal invertebrates from central California to Oregon, 4th edition, pp. 630-631. University of California Press; Berkley.

Dadlez, R., Marek, S. and Pokorski, J. 2000. Geological Map of Poland without Cainozoic Deposits. Ministerstwo Środowiska i Państwowy Instytut Geologiczny; Warszawa.

Davies, W. 1879. On some fish exuviae from the Chalk, Generally referred to Dercetis elongatus AG; And on the new species of fossil Annelide, Terebella lewesiensis. Geological Magazine, 6, 145-148.

Ettensohn, F.R. 1981. Crininicaminus haneyensis, a new agglutinated worm tube from the Chesterian of East-Central Kentucky. Journal of Paleontology, 55, 479-482.

Fauchald, K. and Bellan, G. 2013. Eunice aphroditois (Pallas,
1788). In: G. Read and K. Fauchald (Ed.), World Polychaeta Database [World Register of Marine Species at http://www.marinespecies.org/aphia.php?p=taxdetails\&id $=130053 ; 13.07 .2013]$.

Fauchald, K. and Jumars, P.A. 1979. The diet of worms: a study of polychaete stud guilds. Oceanography and $\mathrm{Ma}$ rine Biology, Annual Review, 17, 193-284.

Ferrero, E. 1989. Biology of stomatopods: proceedings of the 1st International Workshop on Stomatopod Biology, Trieste, September, 2-13, 1985, pp. 1-303. Mucchi; Modena.

Frič, A. 1869. Paläontologische Untersuchungen der einzelnen Schichten in der böhmischen Kreideformation. Arbeiten der geologischen Section für Landesdurchforschung von Böhmen, 1, 1-282. Prague.

Frič, A. 1877. Paläontologische Untersuchungen der einzelnen Schichten, II: Die Weissenberger und Malnitzer Schichten. Studien im Gebiete der Böhmischen Kreideformation. Archiv für die Naturwissenschaftliche Landesdurchforschung von Böhmen, 4, 1-153. Prague.

Frič, A. 1878. Die Reptilien und Fische der Böhmischen Kreideformation, pp. 1-46. Fr. Řivnáč, Prague.

Frič, A. 1883. Palaeontologische Untersuchungen der einzelnen Schichten, III; Die Iserschichten. Studien im Gebiete der Böhmischen Kreideformation. Archiv für die Naturwissenschaftliche Landesdurchforschung von Böhmen, $\mathbf{5}$ (2), 1-140. Prague.

Frič, A. 1889. Palaeontologische Untersuchungen der einzelnen Schichten, IV; Die Teplitzer Schichten - Studien im Gebiete der Böhmischen Kreideformation. Archiv für die Naturwissenschaftliche Landesdurchforschung von Böhmen, 7 (2), 1-120. Prague.

Frič, A. 1893. Palaeontologische Untersuchungen der einzelnen Schichten, V. Studien im Gebiete der Böhmischen Kreideformation. Archiv für die Naturwissenschaftliche Landesdurchforschung von Böhmen, 9 (1), 1-136. Prague.

Friedman, M. 2012. Ray-finned fishes (Osteichthyes, Actinopterygii) from the type Maastrichtian, the Netherlands and Belgium. In: J.W.M Jagt, S.K. Donovan and E.A. Jagt-Yazykova (Eds), Fossils of the type Maastrichtian (Part 1). Scripta Geologica Special Issue, 8 , 113-142.

Fuchs, B. 1935. Terebellen aus dem Weissjura Schwabens. Zentralblatt für Mineralogie, Geologie und Paläontologie, Abteilung B, 210-215.

Fürsich, F.T. 1974. On Diplocraterion Torell 1870 and the significance of morphological features in vertical, spreitenbearing, U-shaped trace fossils. Journal of Paleontology, 48, 952-962.

Gayle, D. 2012. Skinny dipping will never seem like a good idea again: The 10ft-long rainbow 'bobbit worm' that uses scissors to slice prey in two [http://www.dailymail.co.uk/sciencetech/article-2221813/Eunice-aphroditois; 13.07.2013] 
Geinitz, H.B. 1850. Das Quadersandsteingebirge oder Kreidegebirge in Deutschland, pp. 1-345. Craz \& Gerlach; Freiberg.

Gibert, J.M. de 1996. Diopatrichnus odlingi n. isp. (annelid tube) and associated ichnofabrics in the White Limestone (M. Jurassic) of Oxfordshire: sedimentological and palaeoecological significance. Proceedings of the Geologists'Association, 107, 189-198.

Grönwall, K. A. 1912. Maskrör frän Kopingesandestenen. Geologiska föreningen i Stockholm Förhandlingar, 34, 215-220.

Haller, W. 1963. Zur Makrofauna der Oberkreidesedimente im Gebiet Spremberg-Weisswasser. Berliner Geologische Gesellschaft DDR, 8, 152-162.

Häntzschel, W. 1931.Über Sternspuren von Krebsen und Köcherbauten von Würmern in der sächsischen Kreide. Sitzungsberichte und Abhandlungen der Naturwissenschaftichen Gesellschaft ISIS zu Dresden, 1931, 1-18.

Hof, C.H.J. 1998. Fossil stomatopods (Crustacea: Malacostraca) and their phylogenetic impact. Journal of Natural History, 32, 1567-1576.

Hölder, H. 1989. Spuren auf der Spur. Palichnologische und verwandte Notizen über Teredolites, Entobia, Nummipera nov. gen. und einiges andere. Münsterische Forschungen zur Geologie und Paläontologie, 69, 13-30.

Howell, B.F. 1962. Worms. In: R.C Moore (Ed.), Treatise on Invertebrate Paleontology, Part W, pp. W144-W177. Geological Society of America, University of Kansas; New York, Kansas.

Jach, R, Machaniec, E. and Uchman, A. 2012 (for 2011). The trace fossil Nummipera eocenica from the Eocene nummulitic limestones, Tatra Mts., Poland: morphology and palaeoenvironmental implications. Lethaia, 45, 342-355.

Jagt, J.W.M., Walaszczyk, I., Yazykova, E.A. and Zatoń, M. 2004. Linking southern Poland and northern Germany: Campanian cephalopods, inoceramid bivalves and echinoids. Acta Geologica Polonica, 54, 573-586.

Kaminski, M.A. and Wetzel, A. 2004. A tubular protozoan predator: A burrow selectively filled with tubular agglutinated protozoans (Xenophyophorea, Foraminifera) in the abyssal South China Sea. In: M. Bubík and M.A. Kaminski (Eds), Proceedings of the Sixth International Workshop on Agglutinated Foraminifera. Grzybowski Foundation Special Publication, 8, 277-283.

Kern, J.P. 1978. Paleoenvironment of new trace fossils from the Eocene Mission Valley Formation, California. Journal of Paleontology, 52, 186-194.

Kielan-Jaworowska, Z. 1966. Polychaete jaw apparatuses from the Ordovician and Silurian of Poland and a comparison with modern forms. Palaeontologia Polonica, 16, 1-152.

Knox, G.A. and Green, K.M. 1972. The polychaetes of New
Zealand. Part 4. Eunicidae. Journal of the Royal Society of New Zealand, 2, 459-470.

Kowalski, W.C. 1948. Geological outline of Cretaceous deposits in the environs of Solca. Biuletyn Państwowego Instytutu Geologicznego, 51, 5-53. [In Polish with English summary]

Kukuk, P. 1938. Geologie des Niederrheinisch-Westfälischen Steinkohlengebietes, pp. 1-706. Springer; Heidelberg.

Mantell, G.A. 1822. The fossils of the South Downs or Illustrations of the geology of Sussex, pp. 1-327. Lupton Relfe; London.

Mantell, G.A. 1844. The Medals of Creation, or First Lessons in Geology, and in the Study of Organic Remains Volume 2, pp. 1-658. Henry G. Bohn; London.

Mantell, G.A. 1851. Petrifaction and their Teaching, or a Handbook to the Gallery of Organic Remains of the British Museum pp. 1-496. Henry G. Bohn; London.

Marcinowski, R. 1974. The transgressive Cretaceous (Upper Albian through Turonian) deposits of the Polish Jura Chain. Acta Geologica Polonica, 24, 117- 217.

Marcinowski, R. and Radwański, A. 1983. The Mid-Cretaceous transgression onto the Central Polish Uplands (marginal part of the Central European Basin). Zitteliana, 10, 65-95.

Marcinowski, R. and Radwański, A. 1989. A biostratigraphic approach to the mid-Cretaceous transgressive sequence of the Central Polish Uplands. Cretaceous Research, 10, 153-172.

McCosker, J.E. and Castle, P.H.J. 1986. Ophichthidae. In: M.M. Smith and P.C. Heemstra (Eds), Smiths' Sea Fishes, pp. 176-186. Springer; Berlin..

Monaco, P. and Garassino, A. 2001. Burrows and body fossil of decapod crustaceans in the Calcari Grigi, Lower Jurassic, Trento Platform (Italy). Geobios, 34, 291-301.

Monaco, P. and Giannetti, A. 2002. Three-dimensional burrow system and taphofacies in shallow-upward parasequences, Lower Jurassic carbonate platform (Calcare Grigi. Southern Alps, Italy). Facies, 47, 13-16.

Monaco, P., Gianetti, A., Caracuel, J.E. and Yébenes, A. 2005. Lower Cretaceous (Albian) shall-armoured and associated echinoid trace fossils from the Sácaras Formation, Serra Gelada area, southeast Spain. Lethaia, 38, 333-344.

Pemberton, G.S., Spila, M., Pulham, A.J., Saunders, T., MacEachern, J.A., Robbins, D. and Sinclair, I.K. 2001. Ichnology and sedimentology of shallow to marginal marine systems: Ben Nevis and Avalon Reservoirs, Jeanne D'Arc Basin. Geological Association of Canada, Short Course Notes, 15, 1-343.

Pożaryski, W. 1960. An outline of stratigraphy and palaeogeography of the Cretaceous in the Polish Lowland. Prace Instytutu Geologicznego, 30, 377-418.

Ravn, J.P.J. 1915. Om fossile Terebellide-Rør fran Danmark. Meddelelser fra Dansk Geologiske Forening, 4, 224-227. 
Reaka, M.L., Camp, D.K., Álvarez, F., Gracia, A G., Ortiz, M., and Vázquez-Bader, A.R. 2009. Stomatopoda (Crustacea) of the Gulf of Mexico. In: D.L Felder and D.K. Camp (Eds), Gulf of Mexico-Origins, Waters, and Biota. Biodiversity, pp. 901-921. Texas A\&M University Press.

Roll, A. 1931. Die Stratigraphie des Oberen Malm in Lauchertgebiet als Unterlage für tektonische Untersuchungen. Abhandlungen der Preussischen Geologischen Landesanstalt, 135, 1-22.

Rosenkrantz, A. 1920. Craniankalk fra Kjøbenhavn Sydhaven. Danmarks Geologiske Undersøgelse, II Raekke, 36, 1-79.

Rosenkrantz, A. 1967. "Terebella" lewesiensis (Mantell) fra det danske skrivekridt. Meddelelser fra Dansk Geologisk Forening, 17, 194-195.

Rutkowski, J. 1965. Senonian in the area of Miechów, southern Poland. Rocznik Polskiego Towarzystwa Geologicznego, 35, 1-47. [In Polish with English summary]

Santini, F., Kong, X., Sorenson, L. Carnevale, G., Mehta, R.S. and Alfaro, M.E. 2013. A multi-locus molecular timescale for the origin and diversification of eels (Order: Anguilliformes). Molecular Phylogenetics and Evolution (in press). http://dx.doi.org/10.1016/j.ympev.2013.06.016

Suhr, P. 1988. Taxonomie und Ichnologie fossiler Wohnröhren terebelloider Würmer. Freiberger Forschungshefte, $419,81-87$.
Sujkowski, Z. 1926. Sur le Jurassique, le Crétacé, et le Quaternaire des environs de Wolbrom. Sprawozdania Polskiego Instytutu Geologicznego, 3, 382-467. [In Polish with French summary]

Sujkowski, Z. 1934. Roches crétacées entre les villes Pilica et Szczekociny. Sprawozdania Polskiego Instytutu Geologicznego, 8, 39-74. [In Polish with French summary]

Świerczewska-Gładysz, E. and Jurkowska, A. 2013. Occurrence and paleoecological significance of lyssacinosid sponges in the Upper Cretaceous deposits of southern Poland. Facies, 59, 763-777.

Tesch, F.-W. 2003. The Eel, 3rd edition, pp. 408. Blackwell Science; Oxford.

Voigt, E. 1928. Köcherbauten von Würmern in Sedimentärgeschieben. Zeitschrift für Geschiebeforschung, 4, 97104.

Zapfe, H. 1949. Eine rhätische Fauna aus dem Gebiet des Eibenberges bei Ebensee in Oberösterreich. Jahrbuch des Oberösterreichischen Musealvereines, 94, 235-257.

Żeleźniewicz, A., Aleksandrowski, P., Buła, Z., Karnkowski, P.H., Konon, A., Oszczypko, N., Ślączka, A., Żaba, J. and Żytko, K. 2011. Regionalizacja tektoniczna Polski pp. 160. Komitet Nauk Geologicznych PAN; Wrocław.

Ziegler, P.A. 1988, Evolution of the Arctic-North Atlantic and the Western Tethys. American Association Petroleum Geologists Memoir, 43, 1-198. 